\title{
Decarbonization of Ukrainian Economy: Economic and Legal Issues
}

\author{
Liubov Zharova ${ }^{l^{*}}$, and Eremeeva Natalia $^{2}$ \\ ${ }^{1}$ Wyższa Szkoła Ekonomiczno - Humanistyczna, Management Department, 43-300 Bielsko-Biała, ul. \\ gen. Wł. Sikorskiego 4-4c, Poland \\ ${ }^{2}$ The Institute of Economic and Legal Research of NAS of Ukraine, Department of economic and \\ legal research of economic security issues, 01032 Kyiv, 60 Shevchenko blvd., Ukraine
}

\begin{abstract}
The research hypothesis is determined by its focus on forming practical proposals for creating a compelling economic and legal mechanism for the decarbonization of the economy. Based on an integrated approach to the regulation of relevant relations. This approach allows us to identify priority areas for the transformation of legal regulation in the context of decarbonization of the economy, which in turn will help lay the legal foundations for the transition to a carbon-free economy. The practical implementation of the study's scientific results will contribute to implementing the tasks of the Renewed Nationally Defined Contribution of Ukraine to the Paris Agreement. It is planned to pay special attention to the legal aspects of modernization of the coal industry in the context of stimulating the reduction of greenhouse gas emissions. Additional attention was paid to the development of theoretical provisions and practical proposals for the harmonization of state policy in the field of bioenergy, its legal framework with the goals of decarbonization of the energy sector, and ensuring climate neutrality. Keywords: decarbonization, bioenergy, carbonfree economy, climate neutrality.
\end{abstract}

\section{Introduction}

As the global economy recovers from the immediate economic impact of the Covid crisis, attention is increasingly turning to the long-run effects of the shock on the economy's productive potential and the possibility of not only recovering but renewing in the framework of sustainability. The Beyond Recovery initiatives of the United Nations Development Program exemplify the potential for building a new social contract, uprooting inequalities, rebalancing nature, climate, and the economy, and accelerating and scaling digital disruption and innovation [1].

The global nature of climate change necessitates implementing effective mechanisms that can significantly reduce the risks and negative consequences of climate change at the international and national levels. According to the scientific consensus that becomes even stronger in pandemic times, combating climate change requires full decarbonization of our energy systems and zero net greenhouse gas emissions by around 2070. Due to Paris

* Corresponding author: zharova.1@gmail.com 
Agreement [2], countries are negotiating much more modest steps to 2025 or 2030, called Intended Nationally Determined Contributions (INDCs). The long-term goals specified in Articles 2 and 4.1 of the Agreement also establish the time limits. Herefore, it builds on a ratcheting up of aggregate and individual ambition over time. NDCs are submitted every five years to the UNFCCC secretariat. The Paris Agreement provides that successive NDCs will represent a progression compared to the previous NDC and reflect its highest possible ambition to enhance the aim over time. Parties are requested to submit the next round of NDCs (new NDCs or updated NDCs) by 2020 and every five years after that (e.g., by 2020, 2025, 2030), regardless of their respective implementation time frames.

Simultaneously, planned measures and proposed tools for combating climate change were not implemented as efficiently as expected. According to the Climate Action Tracker [3], current global pledges are insufficient (fig. 1).

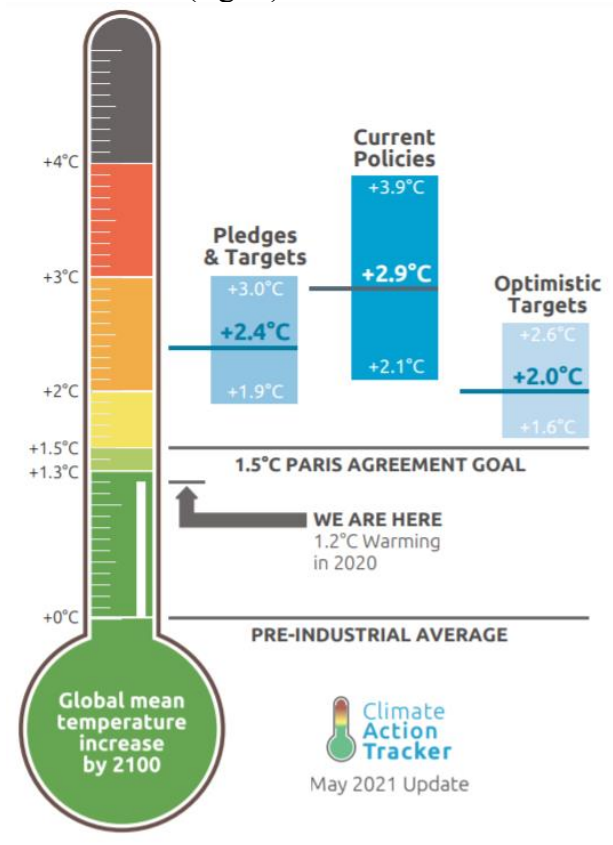

Fig. 1. Climate action announcements and scenarios.

To summarize, decarbonization is part of the global climate change response introduced by several international instruments (the UN Framework Convention on Climate Change, the Kyoto Protocol, the Paris Agreement). It is a tool to mitigate the effects of climate change, is a system of measures to reduce emissions of greenhouse gases to curb the growth of the global average temperature. The commitments made by the member states of the New Global Agreement (limiting the increase of the average temperature of the Earth's atmosphere to $1.5^{\circ} \mathrm{C}$ above pre-industrial levels (Article 2 of the Paris Agreement [2])) determine the transformation of the world economy towards climate neutrality based on so-called green energy transition - replacement of fossil fuel energy systems with renewable electricity and renewable gases (hydrogen, biomethane, synthetic methane); increasing the energy efficiency of national economies. The European Community's response to these challenges has been the European Green Deal [6], a strategy for the transition to a carbon-free economy by 2050 . For Ukraine, the realization of the goals of the Paris Agreement is at the same time a direction of fulfilment of obligations in the context of European integration aspirations.

Ukraine submitted its updated NDC on July 31, 2021, significantly strengthening its 2030 target but still falling short of achieving a $1.5^{\circ} \mathrm{C}$ - compatible ambition level [4]. The NDC 
further includes the goal of reaching climate neutrality no later than 2060 . The submission targets a 65\% reduction below 1990 levels by 2030, including LULUCF, slightly more ambitious than the range proposed at the Climate Ambition Summit in December 2020 (58\% - 64\% below 1990) [5]. The submitted target significantly improves its previous target of at least a $40 \%$ reduction below the 1990 level by 2030 .

\section{Economic and Legal Framework}

The Ukrainian Government approved the Renewed Nationally Defined Contribution of Ukraine to the Paris Agreement, reducing greenhouse gas emissions by $65 \%$ in 2030 from the 1990 level (fig. 1). Commitments to significantly reduce emissions will be met in the face of long-term negative trends in the economy: the ageing of fixed assets, technological equipment, low levels of technical, technological, and energy efficiency against the background of increasing capital investment deficits. Large-scale structural changes require significant energy consumption. However, the functioning of the country's energy sector is primarily due to the use of fossil fuels - coal, natural gas, and fuel oil. The increase in the share of renewable energy sources is limited by the current state of the energy system, which requires a qualitative transformation, and hence additional capital expenditures. At this stage, Ukraine is not ready to completely abandon fossil fuels (energy, metallurgy, utilities and household). Moreover, possible economic growth, increased production of marketable products (electricity, metal, etc.) will increase the relevant emissions and question the fulfilment of international obligations.

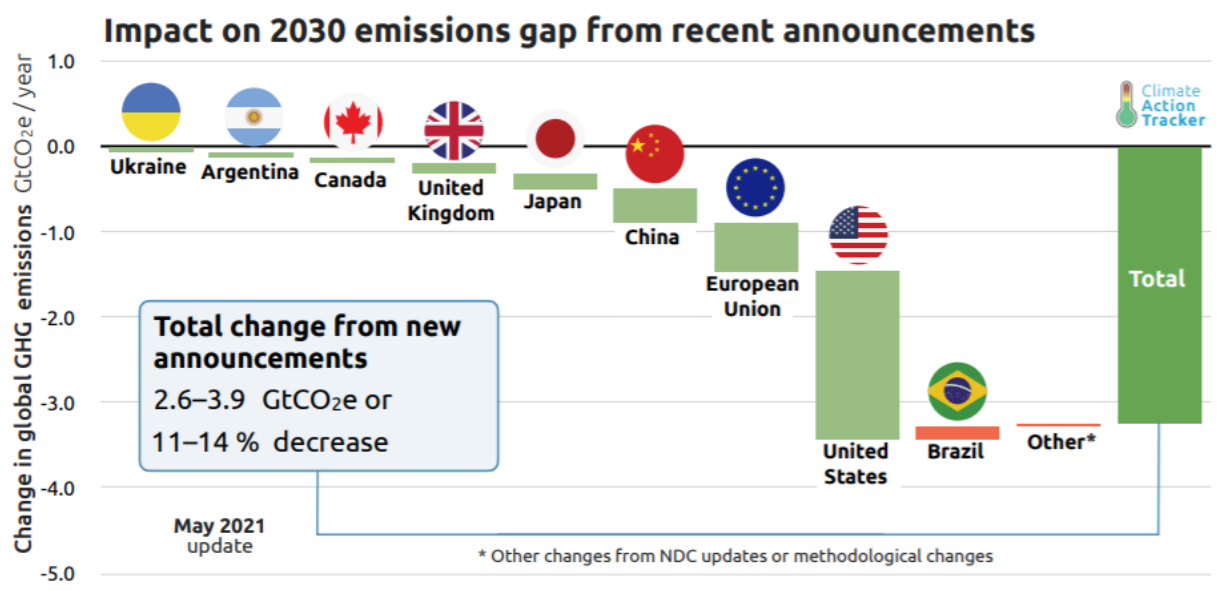

Fig. 2. Impact of recent NDC announcements and submissions since September 2020 on reducing the 2030 emissions gap [3].

We highlighted three key points that are challenging to achieving the updated Nationally Determined Contribution of Ukraine to the Paris Agreement [7].

Political factor. NDC liabilities are determined based on maintaining the transit of natural gas through the territory of Ukraine in the amount of 40-55 billion $\mathrm{m}^{3}$ per year). However, the possibility of the Nord Stream 2 project completion was not taken into account, as well as the probability of gas supply to European countries bypassing the gas transmission system of Ukraine and gas supply to Hungary and Croatia through the "Turkish Stream." Moreover, it can result firstly - the loss of the possibility of import by reverse; secondly - the risk of termination of gas transit through the GTS of Ukraine upon expiration in 2024 of the agreement on the organization of transit between Naftogaz and Gazprom. 
Energy factor. The unpreparedness of Ukraine's economy to abandon fossil fuels in the short term. In addition, the gradual reduction of the share of coal generation in energy requires a proportional transformation of the energy system, finding the optimal ratio between the volume of renewable energy sources and shunting generation, taking into account the threats to national energy security and energy independence.

Financial and economic factors. The lack of domestic investment resources. Characteristic the national circumstances of reducing greenhouse gas emissions in the context of [7] mentioned: considering the significant deterioration of the main assets of large enterprises, modernization of the economy and ensuring sustainable economic development depends on the inflow of investments from both private sources and international financial institutions. According to estimates, the amount of capital investments until 2030, necessary for the implementation of the NDC, is 102 billion euros. Thus, the fulfillment of obligations under NDC occurs against the background of a long-term trend of "narrowing of the primary sources of fixed capital accumulation and shortage of investment resources in the economy [8] and the lack of a sustained long-term upward trend in household incomes. Approaches for redistribution of investments are not yet in place: the internal scheme of emissions trading is in its infancy - at the stage of creating basics of monitoring, reporting, and verification of GHG emissions. As a separate subspecies of securities and a tool for investing in environmental projects, including low-carbon production, Green bonds were introduced only in July 2021. The system of budget support for climate protection projects is also not formed. Therefore, in achieving the goals, Ukraine expects to receive additional climate financing in the form of grants from developed countries and other donors; soft loans; and other financial instruments to create a separate climate fund and increase funding for the decarbonization of the economy through commercial banks and the private sector. The lack of necessary international support puts on the risk of achieving the goal of the NDC.

\section{Steps Forward}

Failure to adapt to EU initiatives threatens negative consequences shortly. The implementation of the concept of "carbon footprint" and the mechanism of border carbon adjustment may be an obstacle to access Ukrainian goods to European markets, investment, and overall inclusion of the Ukrainian economy into the economic space in the EU.

The conflict of interests of economic growth and transition to the path of low-carbon development requires proper economic and legal tools to balance them and reflect a unified system of measures to decarbonize the economy in the legislation.

The groundwork for effective implementation of obligations under the Renewed National Contribution of Ukraine to the Paris Agreement includes: resolving the issues of determining appropriate economic and legal means of decarbonization of the economy, the formation of practical recommendations aimed at ensuring an integrated approach to the legal regulation of public relations.

The existence of several strategies, plans, and concepts for the development of the energy sector, the current state of legal support for decarbonization of the economy is characterized: by the lack of a legally defined system of strategic planning in the energy sector, inconsistency of energy policy with other public policies (economic, environmental, social), as a consequence, an unsystematic and segmented approach to the legislative regulation of relevant relations.

Legal support for the decarbonization of the economy should be carried out according to the vectors defined by the Paris Agreement: effective and progressive response to the urgent threat of climate change based on the recognition of specific needs and particular circumstances of the participating countries; ensuring the consistency of financial flows with the direction of low-carbon and resistant to climate change development; introduction of a 
bottom-up approach, which encourages and ensures participation in mitigation of greenhouse gas emissions not only at the national but also at the regional/local level. For defining the main directions of legal support for implementing these tasks at the level of an integrated act of strategic nature, which would simultaneously provide parameters for updating in the context of decarbonization of Economic and Energy Strategies of Ukraine, other policy documents adopted in the development of their provisions. In the acts of strategic planning, it is necessary to establish the sequence of legislative support of their priorities to ensure the connection between the provisions of the updated legislation under the objectives and the consequences of previously adopted acts.

Among the priority areas for the transformation of legal regulation in the context of decarbonization of the economy is the harmonization of the Renewed National Contribution of Ukraine and the Paris Agreement. In particular, the formation of comprehensive economic and legal mechanisms to reduce greenhouse gas emissions, innovation, and investment support for decarbonization of the economy, increasing energy efficiency. Legal support of Ukraine's "green" energy transition soon should be aimed at transforming energy markets in the context of priority development of renewable energy, introducing a system to stimulate demand for the use of "clean energy." In coal generation, special attention should be paid to the modernization of the coal industry in the context of decarbonization and stimulation of alternative options for reducing greenhouse gas emissions, including reducing associated emissions (not from core activities), which account for significant emissions. Given the prospects for bioenergy development, the urgent task is to reorient the legal regulation from stimulating the quantitative growth of bioenergy potential to ensure proper consideration of the relationship with the goals of sustainable development in general and the adopted climate strategy in particular.

The bottom-up, top-down approach introduced by the Paris Agreement to involve local communities in mitigating greenhouse gas emissions is currently being implemented in public initiatives with the support of international financial organizations and is insufficiently represented in current legislation. Also, we should focus on integrating decarbonization objectives into policies at all levels in the horizontal (sectoral programs and strategies) and vertical (local, regional, and macro-regional levels) levels. Moreover, it should form a comprehensive economic and legal mechanism to reduce greenhouse gas emissions, taking into account the peculiarities of territorial development.

\section{Conclusions}

Decarbonization requires a string of technological revolutions in each of the major emitting sectors. Creating technological revolutions will require different actions in different sectors. In conclusion, we note that further research should focus on developing scientific and methodological approaches to forming adequate legal and economic support for the decarbonization of the economy. The priorities are:

- assess the current state of legal support for the decarbonization of Ukraine's economy, in particular in the context of fulfilling obligations under the Renewed Nationally Defined Contribution of Ukraine to the Paris Agreement;

- to study the world experience of legal support of decarbonization and to determine the ways of its implementation in domestic practice;

- substantiate the priority areas of legal support for the decarbonization of the economy;

- to determine the main directions of economic and legal support of energy sustainability in the conditions of decarbonization; 
- to substantiate the legal basis of the "green" energy transition of Ukraine in the context of the requirements of the Paris Agreement and the European Green Agreement;

- identify the features of the bottom-up (top-down) approach to ensure the participation of local communities in mitigating the effects of greenhouse gas emissions at the regional/local level;

- $\quad$ substantiate the economic and legal principles of decarbonization at the regional and local levels.

Based on the presented research results, the following steps will be: designing scientific and methodological recommendations for the adaptation of foreign experience in this area; developing the multidisciplinary mechanisms of legal regulation for decarbonization. It is also planned to identify ways to harmonize the priority areas of legal support for the decarbonization of the economy with the provisions of the Renewed National Defined Contribution of Ukraine to the Paris Agreement. It will also be essential to develop a set of systematically agreed proposals to improve the legislative and regulatory framework governing the decarbonization of the economy.

\section{References}

1. Abidoye, B., Felix, J., Kapto, S. \& Patterson, L. (2021). Leaving No One Behind: Impact of COVID-19 on the Sustainable Development Goals (SDGs). New York, NY and Denver CO: United Nations Development Programme and Frederick S. Pardee Center for International Futures.

2. Paris Agreement FCCC/CP/2015/10/Add.1 (2015) https://unfccc.int/process/conferences/pastconferences/paris-climate-changeconference-november-2015/paris-agreement

3. Climate Action Tracker Warming Projections Global Update, (May 2021) https://climateactiontracker.org/documents/853/CAT_2021-05-04_Briefing_GlobalUpdate_Climate-Summit-Momentum.pdf

4. CAT Climate Target Update Tracker. Ukraine (June 31, 2021) https://climateactiontracker.org/climate-target-update-tracker/ukraine/

5. Climate ambition Summit. United Nations, the United Kingdom, and France, in partnership with Chile and Italy (December 2, 2020) https://www.climateambitionsummit2020.org/ondemand.php

6. European Green Deal. COM/2019/640 final (Brussels, 11.12.2019) https://eurlex.europa.eu/legal-content/EN/TXT/?uri=CELEX\%3A52019DC0640

7. Ukraine First NDC (Updated Submission) 31.07.2021 https://www4.unfccc.int/sites/NDCStaging/pages/Party.aspx?party=UKR

8. Шовкун I.A. Неоіндустріалізація в Україні: чи є макроекономічні передумови та інвестиційний потенціал? Економіка і прогнозування. № 4. с.48-69 (2016) 